\title{
Attitudes, Awareness, and Roles of Parents in Children's Musical Instrument Learning at The Klang Valley Music Centre
}

Chang Lok Yew, Ang Mei Foong

To Link this Article: http://dx.doi.org/10.6007/IJARBSS/v11-i11/11655

DOI:10.6007/IJARBSS/v11-i11/11655

Received: 12 September 2021, Revised: 17 October 2021, Accepted: 09 October 2021

Published Online: 25 November 2021

In-Text Citation: (Yew \& Foong, 2021)

To Cite this Article: Yew, C. L., \& Foong, A. M. (2021). Attitudes, Awareness, and Roles of Parents in Children's Musical Instrument Learning at The Klang Valley Music Centre. International Journal of Academic Research in Business and Social Sciences, 11(11), 1706-1721.

Copyright: (c) 2021 The Author(s)

Published by Human Resource Management Academic Research Society (www.hrmars.com)

This article is published under the Creative Commons Attribution (CC BY 4.0) license. Anyone may reproduce, distribute, translate and create derivative works of this article (for both commercial and non0-commercial purposes), subject to full attribution to the original publication and authors. The full terms of this license may be seen at: http://creativecommons.org/licences/by/4.0/legalcode

Vol. 11, No. 11, 2021, Pg. 1706 - 1721

Full Terms \& Conditions of access and use can be found at http://hrmars.com/index.php/pages/detail/publication-ethics 


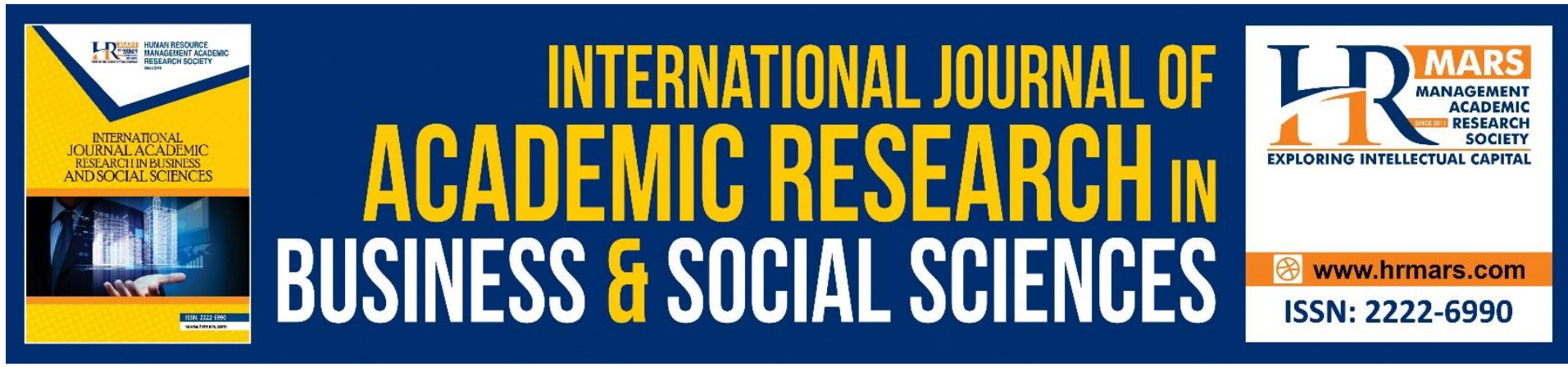

\title{
Attitudes, Awareness, and Roles of Parents in Children's Musical Instrument Learning at The Klang Valley Music Centre
}

\author{
Chang Lok Yew, Ang Mei Foong \\ Department of Music, Faculty of Human Ecology, Universiti Putra Malaysia, 43400 UPM \\ Serdang, Selangor Darul Ehsan, Malaysia \\ Email: meifoong@upm.edu.my
}

\begin{abstract}
Parents always play a pivotal role in children's musical development. This study investigated parental attitudes and awareness of parental roles in children's music learning. Ten parents in Kuala Lumpur who have been sending their children (7-12 years old) to learn musical instrument in a music centre participated in this research. The data were collected through a set of interview question based on Youm's parental attitude framework (2013). The findings revealed that the parents in Klang Valley, Malaysia have clear goals for their children through music learning but lack the initiative and confidence to guide their children when they are practising at home; local parents emphasized the training of independence and responsibility for their children by providing minimal assistance. Although they were aware that parental roles are important, they showed a low willingness to guide their children at home, as well as low willingness on expanding musical knowledge, and a low motivation to enrich and perform their roles.
\end{abstract}

Keywords: Music Education, Parental Attitudes, Awareness of Parental Roles, Children's Music Learning, Music Instrumental Learning

\section{Introduction}

Music learning is an all-around beneficial activity for children, it acts as a catalyst to improve individual's intelligence and emotion quotient (Ritter \& Ferguson, 2017; Skoe \& Kraus., 2012), also music learning is a tool to maintain health (Chanda \& Levitin, 2013; Trappe \& Voit, 2016), as well as to accelerating brain development in children especially in language acquisition and reading techniques (Gersema, 2016), and strengthening memory skills (Skoe \& Kraus, 2012). Music learning itself is important, however, children might need sufficient support from their parents to achieve an efficient learning outcome. Youm (2013) has denoted that parent may be considered as the first and the most important teacher besides the child's private or school music teachers as children spend most of their time with parents at home and they may begin their music education at home with the family members (Youm, 2013).

Most children need support from their parents to become committed in their challenging yet fulfilling journey of music learning, this support is significant in musical instrument learning 
(Davidson et al., 1996), as parental involvement can be seen in significantly influencing the processes of the children's musical achievement (McPherson, 2009). Furthermore, close parent-child bonding is key in helping the children to become mastery-oriented, also encouraging the children to be willing to utilize more sophisticated cognitive skills to attain better achievement (McPherson, 2009).

There are also research reports that show consistent positive effects of parental influences on student musical achievements, attitudes, and behaviour in the learning progress (Pomerantz et al., 2005).

Although many research in the past showed a positive relationship between parental involvement and musical achievements, there is also research that revealed poor parental attitudes when intervening in the learning process. Kilic (2012) found out that parents have inadequate passion for their children's music learning and insufficient sensitivity to the needs that arise from music lessons. A consequence to this, students' attitudes in music learning can be adversely affected by their parents' responses and parental attitudes (Kilic, 2012).

There were studies that look into teachers and young students' relationship for an effective music learning (Ku, 2006; Nam, 2006), however, it is quite rare that parental roles and parental awareness on their roles in music learning were studied. Given the importance of parental roles in a child's music learning process, understanding both the parental awareness of their parental roles as well as the parental attitudes in children's music learning is important for a better music learning experience for children.

\section{Attitudes}

Bohner and Dickel (2011) explained that attitudes are the evaluation of an object of thought such as anything that a person holds in mind, whilst Allport (1953) denoted that attitude are important to social psychology. Attitudes are also temporal judgments constructed on the spot from the information at hand (Conrey \& Smith, 2007; Gawronski \& Bodenhausen, 2007; Schwarz, 2007). This explains that attitudes can be changed depending on the on-the-spot situation such as one's sudden desires or needs.

\section{Awareness on Parental Roles}

Besides, Philip (1984) explained that people's awareness on a certain matter can only be detected when they are fully aware of the matters. Some researchers showed parental support is minimal during early years of learning and this can result in the students having a low achievement; however, in some cases, the parental support tends to raise during the student's teenage years, when the awareness raises due to a change of goal in the long learning process. This happens when parents are desired for their children to maintain the learning momentum (Davidson et al., 1996).

Margiotta (2011) further denotes that parental attitude are related to their children's determination in getting involved with any activities; whilst Zimmermann and Cleary (2006) further explained that children may need assistance or support from others particularly in situations where they are unable or unwilling to set goals and anticipate the implication of their actions. This is because young children are often unable to recognize the difficult areas of a piece or the mistakes they are making as their discernment ability is still immature 
(Margiotta, 2011). At this point, parents should be aware of the situation by guiding and advising their children with adequate supports, positive comments or actual assistance to make sure the child can have a positive mindset to further their learning commitment and an acquired motivation when coming to music learning especially on learning an instrument (Margiotta, 2011).

Therefore, the parents' awareness on their parental roles as a coordinator or facilitator has to be undertaken by the parents. When explaining awareness, Philip (1984) explained that people's awareness can only increase when they fully understand the urgency of a certain matter, as well as a comprehensive knowledge background. People might be raising their awareness by learning new knowledge, technique or skills; as well as through the journey of achieving a goal (Youm, 2013).

To further explain about goals and learning, Ogbeiwi explained that goals are objectives or aims and targets for one to do something, where a clear goal helps to effectively motivate an attainment (Ogbeiwi, 2018). This implies that the success in children's music learning can be affected by the setting of goals by children themselves as well as from their parents. Hence, understanding the goals from parents can reveal parental attitudes on children's music learning, as the parental attitudes are dependent on the goals they set, the knowledge about music learning as well as the needs they desire to have. (Youm, 2013; Ogbeiwi, 2018).

\section{Objectives of Study}

Children may need assistance from parents for effective music learning, by understanding the parental attitudes as well as parent's awareness on parental roles could lead to a more successful music learning. However, what exactly are the local parents' perspectives on this remained unknown. There is little research that reports the parental attitudes and the awareness of parental roles in children's music learning locally.

Hence, the purpose of this study is to investigate the parental attitudes and the awareness of parental roles in their children's music learning that focuses on individual music instrument learning from private music centres in Klang Valley, Malaysia. The investigation on parental attitudes and the awareness of parental roles will be explored through parent's goals, parents' knowledge and parents' needs. This study only focused on the children who received individual music instrumental lessons from the private music studio.

\section{Materials and Methods \\ Research Questions}

There are two main research questions: (1) What are the local parents' parental attitudes in children's music learning? (2) What is the local parents' awareness of parental roles in children's music learning?

\section{Research Design}

Goals, knowledge and needs are associated with one's attitude and awareness on the role one's playing (Youm, 2013), these laid a theoretical scaffolding in this present study and formed the conceptual framework of this study (as seen in figure 1). 


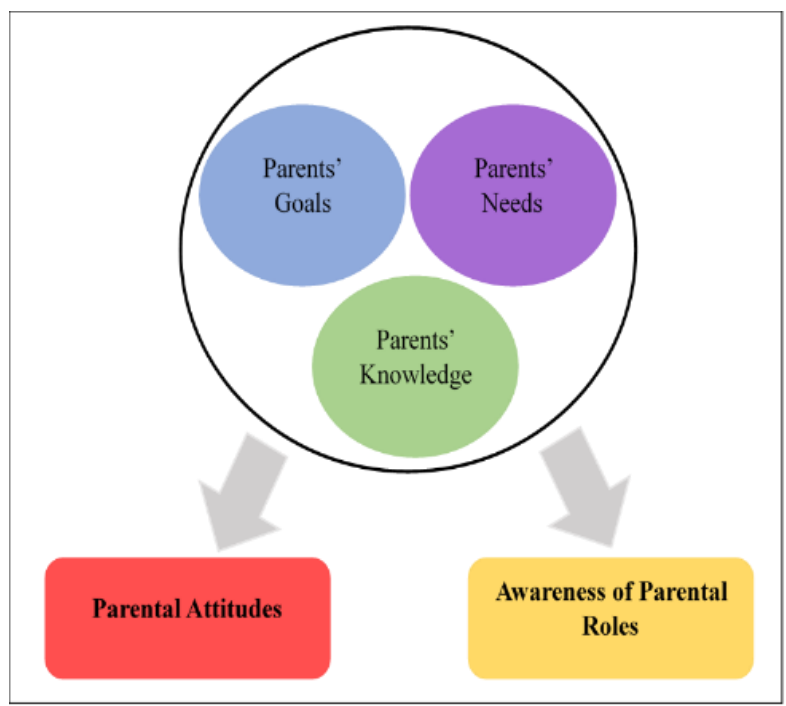

Figure 1. Conceptual Framework of Parental Attitudes and Awareness of Parental Roles in Children's Music Learning

Interview questions were structured along the three main themes: goals, knowledge, and needs. Through the lens of the three said-themes, parental attitudes and the awareness of parental roles were investigated.

\section{Participants}

10 parents whose children aged between 7-12 years old, who are attending music lessons while the study was conducted were recruited as research participants in this study. The participants were recruited through convenience sampling following a snowball sampling. Among the 10 participants, 6 were female, 4 were male, with the age ranging from 30 years old to 49 years old; and their children's year of music learning range from less than a year to more than 6 years.

\section{Data Collection}

One-to-one online interviews were conducted via an online platform such as ZOOM or Google Meet. Each interview session took approximately 25 to 40 minutes. The interview session was recorded either in audio or video format, using the built-in recording function by Zoom or Google Meet. As shown in Table 1, the interview questions are open-ended questions and the sessions were conducted in English. Field notes were taken during each interview to enable researchers to better recall the interview situations and participants' statements. 


\section{Table 1}

\section{Interview Questions}

\begin{tabular}{|c|c|c|}
\hline \multirow{2}{*}{$\begin{array}{l}\text { Categories } \\
\begin{array}{l}\text { Goals-related } \\
\text { questions }\end{array}\end{array}$} & \multicolumn{2}{|c|}{ Interview Questions } \\
\hline & a) & $\begin{array}{l}\text { Why do you let your child attend music lessons? What are the initial goals } \\
\text { that you want your child to achieve from the music lesson? }\end{array}$ \\
\hline & b) & Are the goals changed post music lessons after a period of time? \\
\hline & c) & Does the outcome of the music lesson meet your goals? \\
\hline & d) & $\begin{array}{l}\text { To reach the goals, have you tried to/ will you assist your children while } \\
\text { practising? }\end{array}$ \\
\hline & e) & $\begin{array}{l}\text { Please describe the assistance that you can provide to your child. (e.g.: How } \\
\text { many hours can you spend to assist your children? What is the way to assist } \\
\text { your children?) }\end{array}$ \\
\hline & f) & $\begin{array}{l}\text { Would you recommend or have you recommended the music lesson to other } \\
\text { parents? Why or why not? }\end{array}$ \\
\hline
\end{tabular}

Knowledge-

related

questions a) Do you have related music or music education knowledge?

b) Please describe the details about the music lesson that your child is attending (e.g.: the objective of the course, the examination board, etc.)

c) Do you think it will be more helpful for your children to be successful in their music learning journey if you have some related knowledge to assist your children? Why?
Needs-
a) Do you interact with your children musically at home?
related
b) Do you think there is a necessity that you need to guide your children at home questions while they are practising?
c) What method do you prefer to learn to guide your child? (e.g.: reading appropriate books or other materials, taking private lessons, going to libraries, going to concerts, attending workshops, attending lectures) If not, please explain the reasons.
d) Do you think you need to expand your understanding of music education in order to motivate your children in their music learning? Why do you need this and why not?
e) Have you attended workshops or lectures aimed to educate parents about their children's musical development? If so, when and how was it? If not, do you want to attend the workshops or lectures in the future?
f) If you have a chance to enhance yourself to expand your understanding in music education, would you want it?
g) If yes, what techniques or skills would you like to learn or study (e.g.: instrument lessons, how to interact musically with my child, music theory, how to read music, lecture about child development, classical music for music appreciation with my child, how to find children's music resources on the Internet)? 


\section{Data Analysis}

Descriptive analysis method was used to analyse the data obtained from the questionnaire. The interviews were transcribed, multiple methods of data analysis were used which include narrative analysis, coding, inductive analysis and constant comparison. In the process of narrative analysis, field texts such as field notes, conversations, interviews, photo or life experience were used as the unit of analysis to research and understand the way people create meaning in their lives as narratives. Next, open coding was employed when analysing the interview transcripts. During the coding process, inductive analysis was applied to examine the details collected from the interviews by discovering patterns, themes and categories in one's data (Patton 2002). Moreover, constant comparison was also used during the coding process to compare one or more categories to determine its relevance and compare it with other segments of data which similarly categorized (Schwandt, 2011) by discovering some new relationships between categories as well as some similarities and differences among the participants' statements.

\section{Results}

This study investigates the parental attitudes and the awareness of parental roles in Klang Valley, Malaysia through the three themes: parents' goals, parents' knowledge and parents' needs. Findings of each theme are described below:

\section{Parents' Goals}

\section{Table 2}

The Three Themes, Sub-Themes and Responses on Parents' Goals

\begin{tabular}{|c|c|c|}
\hline Themes & Sub-Themes & Responses \\
\hline \multirow[t]{3}{*}{$\begin{array}{l}\text { Parents' Goals } \\
\text { in General }\end{array}$} & $\begin{array}{l}\text { Facilitating } \text { Child's } \\
\text { Development }\end{array}$ & $\begin{array}{ll}\text { - } & \text { Musical } \\
\text { - } & \text { Emotional } \\
\text { - } & \text { Social } \\
\text { - } & \text { Physical } \\
\text { - } & \text { Creative } \\
\text { - } & \text { Personal }\end{array}$ \\
\hline & Life Enrichment & $\begin{array}{ll}\text { - } & \text { Musical experiences } \\
\text { - } & \text { Music Enjoyment }\end{array}$ \\
\hline & $\begin{array}{l}\text { Future } \\
\text { Enrichment }\end{array}$ & $\begin{array}{l}\text { - } \quad \text { Acquisition of Music Certification } \\
\text { - } \quad \text { Additional Career Options }\end{array}$ \\
\hline \multirow{3}{*}{$\begin{array}{l}\text { Parents' } \\
\text { Satisfaction on } \\
\text { Goal-achieving } \\
\text { from the Music } \\
\text { Lesson } \\
\text { Outcome }\end{array}$} & Satisfied & $\begin{array}{ll}\text { - } & \text { Concentration } \\
\text { - } & \text { Happy Emotion }\end{array}$ \\
\hline & Partially Satisfied & $\begin{array}{ll} & \text { Improving in Concentration } \\
\text { - } & \text { Improving in Musical Senses and Skills }\end{array}$ \\
\hline & Not Satisfied & $\begin{array}{ll}- & \text { Early Period of Music Learning } \\
- & \text { Unable to see the Outcomes }\end{array}$ \\
\hline \multirow{3}{*}{$\begin{array}{l}\text { Parents' } \\
\text { Assistance to } \\
\text { the Children in } \\
\text { Achieving the } \\
\text { Parents' Goals }\end{array}$} & $\begin{array}{l}\text { Always } \\
\text { Assistance }\end{array}$ & $\begin{array}{ll} & \text { Comments Giving } \\
\text { - } & \text { Paying Attention in Children's Practise Sessions } \\
\text { - } & \text { Motivating Children }\end{array}$ \\
\hline & $\begin{array}{l}\text { Sometimes } \\
\text { Assistance }\end{array}$ & $\begin{array}{ll}\text { - } & \text { Emphasizing Training of Responsibility and } \\
\text { Independence } & \\
\text { - } & \text { Mostly Accompanying Children at Younger Ages }\end{array}$ \\
\hline & $\begin{array}{l}\text { Never } \\
\text { Assistance }\end{array}$ & $\begin{array}{l}\text { - Emphasizing Training of Responsibility and } \\
\text { Independence } \\
\text { - Providing Essential Items: Books, Transportation, etc. }\end{array}$ \\
\hline
\end{tabular}


As summarized in Table 2, there were three themes emerged from the participants' responses that are related to parents' goals in their children's music learning: parents' goals in general, parents' satisfaction on goal-achieving from the music lesson outcome, and parents' assistance to the children in achieving the parents' goals.

In the first theme, where the parents' goals were investigated, interesting findings were identified when asking about parents' goals in their children's music learning, and the goals mentioned by the research participants can be summarized into three main sub-themes: (1) Facilitating Child's Development; (2) Life Enrichment; and (3) Future Career Enrichment.

Participants' responses were noted in Table 2, where the first sub-theme that emerged from the Parents' Goals in General was Facilitating Child's Development and it is summarized into six different dimensions, this includes: Musical development, Emotional, Social, Physical, Creative, and Personal development.

As mentioned by one of the participants, when parent talked about their goal in the musical development dimension, the participant said:

"I'd like my child to know how to appreciate music because I can really see the beauty of music. I hope my children can learn to appreciate the beauty of music."

In addition, some parents hoped that music lessons can help to regulate their children's emotion and mood:

"I am convinced that music is a platform to release our emotions such as sadness, happiness and others..."

Another prominent theme that emerged when the parents were asked of their goals was Life Enrichment. Parents expressed their wish to enrich their children's lives by providing them opportunities to experience musical elements, to explore music, to gain extra skills to enhance themselves, to build up their musical interest, to enjoy music playing and to seek music playing as a beneficial activity in their life. As they described in the interviews:

"I totally agree that music playing can give a different meaning in individuals' lives and it also can be a way to express yourself."

"I hope I can explore my children's interest especially in music playing, trying to build up her interest in music learning and make her enjoy the music playing."

The last theme that emerged in the discussion on goals was Future Career Enrichment. Parents in this study explained that they hoped a good foundation in music skills can create different pathways of careers in future, as described by one of the participants as follow:

"We [as parents] need to help them to prepare various routes in life and this will also provide an alternative option for them in the future for career selection."

The second theme emerged from the finding was Parents' Satisfaction on Goal-achieving from the Music Lesson Outcome, where 7 parents commented that their children's learning met their goals partially. Parents further explained that they did observe improvements and changes in their children's attitudes after taking music lesson: 
"I actually can see some improvement in their behaviour like my child becoming more concentrated in doing things but I think they haven't met the goals."

Apart from this, 2 parents agreed fully that their children's learning have fully met their goals, and expressed their satisfaction that they observed their children to have been able to concentrate more in their other tasks; whilst 1 parent commented that it was still too early to detect changes in the child as the child was still at the early stage on the music learning journey:

"I think now is quite early to say achieving the goals that I set. I think my children still have a big space to work for their music learning."

The third theme emerged from the finding was Parents' assistance to the children in achieving the parents' goals, where five parents mentioned that they provided some assistance to their children when the children are practicing at home:

"I will give some comments for them when they play wrongly in some parts." There were also three comments from parents that said they provide minimal assistance to their children as they emphasized more on the training of responsibility and independence in their children.

"I will leave this practice routine to my children as a responsibility for them to achieve and I hope they will become more independent for their own life. Thus, I decided not to accompany them frequently for now."

Furthermore, there were also comments from parents who mentioned that they do not assist their children at all. They only provided necessary learning materials or services to the children such as books and other learning materials and provided transportation. 


\section{Parents' Knowledge}

\section{Table 3}

The Three Themes, Sub-Themes and Responses on Parents' Knowledge

\begin{tabular}{|c|c|c|}
\hline Themes & Sub-Themes & Responses \\
\hline \multirow{5}{*}{$\begin{array}{l}\text { Parents' } \\
\text { Level }\end{array}$} & Professional & - Music School Principal \\
\hline & Musicians & - Soprano Singer \\
\hline & & - University Lecturer from Music Department \\
\hline & $\begin{array}{l}\text { Amateur } \\
\text { Musicians }\end{array}$ & - One-year of Piano Learning Experiences \\
\hline & Non-musicians & - No Musical Knowledge \\
\hline $\begin{array}{l}\text { Parents' } \\
\text { Understanding on }\end{array}$ & Very Clear & $\begin{array}{l}\text { - Clear on the structure of the music class, the } \\
\text { examination system and the examination board }\end{array}$ \\
\hline \multirow[t]{2}{*}{$\begin{array}{l}\text { Children's Music } \\
\text { Lesson }\end{array}$} & Partially Clear & $\begin{array}{l}\text { - Vague on the structure of the music class, the } \\
\text { examination system and the examination board }\end{array}$ \\
\hline & Not Clear & $\begin{array}{l}\text { - No Information for the structure of the music class, } \\
\text { the examination system and the examination board }\end{array}$ \\
\hline \multirow{4}{*}{$\begin{array}{l}\text { Parents' Opinion on } \\
\text { the Helpfulness of } \\
\text { Parents' } \\
\text { Knowledge } \\
\text { Towards Children's } \\
\text { Music Learning }\end{array}$} & Will be Helpful & $\begin{array}{ll}- & \text { Easier to Transfer Correct Information } \\
\text { - } & \text { Children Confident in Parents' Teaching } \\
\end{array}$ \\
\hline & Maybe Helpful & - $\quad$ Added Advantage but not the Main Key \\
\hline & $\begin{array}{l}\text { in Specific } \\
\text { Cases }\end{array}$ & $\begin{array}{l}\text { - Express Learning Progress but Might Overwhelming } \\
\text { for Children }\end{array}$ \\
\hline & No Helpful & $\begin{array}{l}\text { - Full Responsibility taken by Music Teacher (Parents } \\
\text { can teach by themselves if they have knowledge) }\end{array}$ \\
\hline
\end{tabular}

There were also three main themes emerged from parents' knowledge domain, where parents' music level, parents' understanding on children's music lesson, and parents' opinion on the helpfulness of parents' knowledge on children's music learning, were summarized. When investigating parents' knowledge on music, it is found that the research participants' music background was very varied, ranging from professional musicians which includes the principal of a music school, professional singer (soprano) and a university music lecturer, to amateur musicians and parents who have totally no music background.

Professional musicians showed a strong understanding of their children's music lessons. They understand the structure of the music class, the examination system and the examination boards. The amateur musician-parents were partially clear about their children's music lesson as they can roughly describe the structure of music class but they seem to have less confidence while explaining the lesson structures and examination systems; whilst parents with no background in music had totally no knowledge at all in the contents of their children's music lessons.

Parents' opinion on whether possessing musical knowledge is necessary when it comes to guiding their children in the music learning journey was also varied. Five participants commented that it would be helpful to the children if parents were having some knowledge about music, quoting from them: 
"This will become easier to teach them because a person that does not know anything to teach a person that knows something is very difficult."

Another two parents mentioned that it would be an added advantage if the parents with some musical knowledge however it is not necessary. They believed that parents' knowledge is not the main key to make the children succeed in their music learning but only an added advantage:

"I don't think parents' knowledge is the main reason for success in children's music learning. I think support from parents is more important than having some related knowledge."

On the other hand, another two parents emphasized that music teachers' knowledge were more important than the parents' knowledge and music teachers have to take the whole responsibility to teach the children, stating that there would be no need to recruit teachers if parents can teach their children by themselves.

Another parent mentioned that there are both pros and cons for parents to possess musical knowledge, elaborating that child may find the learning process too overwhelming if they were to receive more information from their parents, other than their teachers:

"I can see that this will express my children's learning process but sometimes this will also make the children overwhelmed for receiving much knowledge from parents." 


\section{Parents' Needs}

Table 4

The Three Themes, Sub-Themes and Responses on Parents' Needs

\begin{tabular}{|c|c|c|}
\hline Themes & Sub-Themes & Responses \\
\hline \multirow[t]{3}{*}{$\begin{array}{l}\text { Opinions on the } \\
\text { Needs of } \\
\text { Guidance from } \\
\text { Parents } \\
\text { Children }\end{array}$} & Needed & $\begin{array}{l}\text { - Wish to learn methods in guiding children: reading } \\
\text { related books, searching online resources and } \\
\text { materials, taking private lessons, going to libraries } \\
\text { and attending concerts, workshops or lectures. }\end{array}$ \\
\hline & $\begin{array}{l}\text { Needed for } \\
\text { Specific Situation }\end{array}$ & $\begin{array}{l}\text { - For beginner stage or the younger children } \\
\text { - } \quad \text { For the children who were weak in music learning }\end{array}$ \\
\hline & Not Needed & $\begin{array}{l}\text { - Children's Responsibility } \\
\text { - Independency }\end{array}$ \\
\hline \multirow{2}{*}{$\begin{array}{l}\text { Willingness in } \\
\text { Expanding } \\
\text { Parents' } \\
\text { Understanding } \\
\text { in Music or } \\
\text { Music Education }\end{array}$} & $\begin{array}{l}\text { Willing to but not } \\
\text { now }\end{array}$ & $\begin{array}{l}\text { - } \text { Existed Knowledge is not Always Compatible } \\
\text { - Wish to expand the understanding if have some } \\
\text { extra free time but not now }\end{array}$ \\
\hline & Not Willing to & $\begin{array}{l}\text { - The Roles of Music Teacher is More Important } \\
\text { - Parents only need to provide financial support and } \\
\text { encouragement }\end{array}$ \\
\hline \multirow{3}{*}{$\begin{array}{l}\text { Attending } \\
\text { Workshops or } \\
\text { Lectures for } \\
\text { Children's } \\
\text { Musical } \\
\text { Development }\end{array}$} & Attended & - Right Brain Training Related Workshop \\
\hline & $\begin{array}{l}\text { Never Attended } \\
\text { but Interested }\end{array}$ & - Availability of Short-Term Workshop or Lecture \\
\hline & $\begin{array}{l}\text { Never Attended } \\
\text { and not Interested }\end{array}$ & - Not Interested to Join \\
\hline
\end{tabular}

From the interview, all parents mentioned that they were willing to spend time interacting with their children at home but only on verbal activities such as singing instead of playing the musical instrument together. There were three themes that emerged from the participants' responses: Opinions on the needs of guidance from parents to children, Willingness in expanding parents' understanding in music or music education, and Attending workshops or lectures for children's musical development.

Two parents who commented that guidance from parents is necessary when the children were practising at home. The parents also mentioned that they would learn some methods to guide their children at home such as reading related books, searching online resources and materials, taking private lessons, going to libraries and attending concerts, workshops or lectures.

Half of the parents commented that it is not necessary to guide their children when they are practising at home as they emphasized more on the training of independence and responsibility of their children:

"I think independence is the important element for the children, so I will leave this practice the responsibility to them." 
Two parents shared their experiences that there is a need to guide their children at home for specific cases such as the younger children or weak students at the beginning stage of music learning:

"I think [guidance from parents] will become important when children are in the beginner stage or for the younger children."

"I think for the children who were weak in music learning is necessary."

Even though many responses stated that it is not necessary to guide their children at home, parents do agree that trying to understand more about music and to possess certain music knowledge is important for their children however they expressed a minimal initiative in doing so:

"I think existing knowledge is not always compatible, so I wish to expand my understanding if I have some extra free time but not now."

The responses also summarized some knowledge or skills the parents desired to learn, for example, the methods in searching for children's music resources on the internet, the ability to understand music theory, the way to interact with children on music, understanding about child development and classical music for music appreciation and the ability to read music. Besides, another five parents mentioned that they are not willing to expand their understanding because they thought the role of a teacher is more important as compared to parents and their responsibility is to only provide financial support and encouragement.

Nine parents never attend any workshop or lecture that is related to children's musical development. Subsequently, they were asked about their willingness to join any related workshop or lecture in the future. 6 out of 9 parents were willing and interested to join any workshop or lecture, only when they are free and if the workshop is a short-term workshop. There were also three parents who commented that they were not interested at all in joining any workshop or lecture.

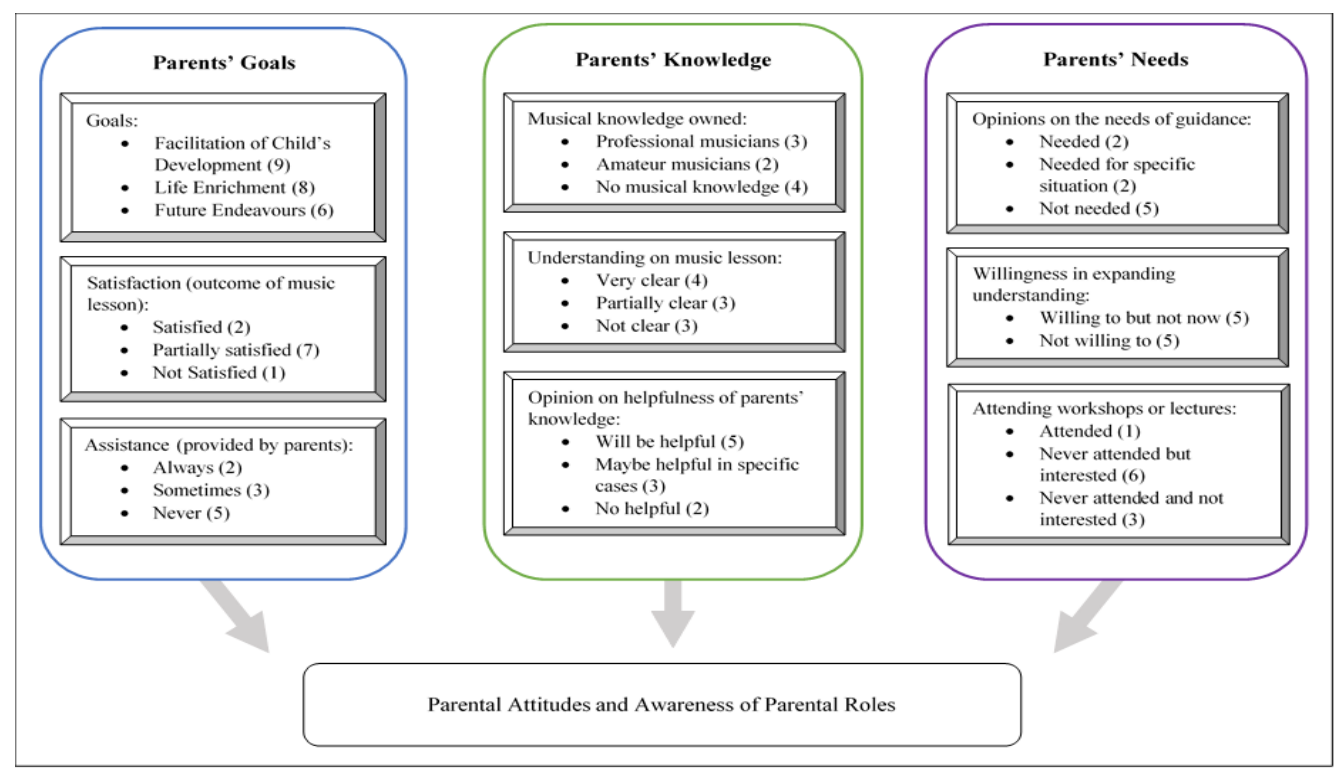

Figure 2. Summary of Responses Based on Parents' Goals, Knowledge and Needs at the Relationship of Parental Attitudes and Awareness of Parental Roles 


\section{Conclusion and Discussion}

The findings from this study showed that local parents have a clear goal in their children's music learning and their goals are persistent. Clear goals in music learning are reflected in parental attitudes and this helped the children in achieving better in their music learning journey, as the clear goals effectively help to motivate an attainment (Ogbeiwi, 2018).

A clear goal also helped parents to keep track of the progress of their children's music learning, portraying parents' positive attitudes in their children's music learning, leading their children in a positive direction.

As Margiotta (2011) denoted, parent's understanding on the importance of musical practice at home can lead to a higher awareness of their parental role in encouraging their children's music practice, this is also affirmed in the awareness among the local parents. Local parents are aware of their role in encouraging the home practice commitment, however, local parents' actual involvement in their children's practice was very minimal. Local parents often remind the children to do musical practice on their own but rarely accompany the practice by sitting aside nor assisting the practice, as local parents aimed on emphasizing the training of music learning independency and responsibility in their children.

The finding of this research showed that many local parents possessed musical knowledge, this could indicate that the local parents who send children to music learning could be music enthusiasts themselves, or parents who had a musical background tend to send children for music learning. However, possessing musical knowledge might not result in positive parental attitudes when dealing with giving musical support at home, this is in contrary to Margiotta's (2011) denotation, where she suggested that parents with music knowledge tends to offer stronger musical support to their children and hence were able to aid their children to achieve a learning goal.

Local parents' attitudes toward guiding their children in music learning journey was generally low, especially the parents with minimal musical knowledge, who demonstrated not only a low confidence in guiding the children in their home music practice, but also a low willingness and interests to do so. Instead of parental guidance, local parents feel that music teachers should play a pivotal role in guiding their children, rather than the parents themselves. Furthermore, local parents aimed on training independency and responsibility in their children and hence rarely willing to provide guidance and support when dealing with home music practice.

Local parents with and without musical knowledge both showed a low understanding on the details of their children's music learning, showing a low awareness in the learning content of their children. Slightly in contrast to Hallam's (1998) statement that suggested only parents with low music knowledge showed low awareness of their potential parental role.

Local parents did not think there was a necessity to guide their children's home music practice possibly also due to the reasons of wanting to train their children on being independent and responsible to their own music learning; furthermore, local parents think that teachers should be the responsible in giving guidance and support in children's music learning. The responses from the local parents showed a low awareness in their potential parental roles. 
Zimmermann \& Cleary (2006) stated that young children may need assistance or support from others particularly in situations where they are unable or unwilling to set goals and anticipate the implication of their actions because young children are often unable to recognize the difficult areas of a music piece or the mistakes they are making as their discernment ability is still immature (Margiotta, 2011). Parents could have played their roles better in guiding their children onto setting a clear goal in music practice at home, low awareness in parental roles could hinder effectiveness in music learning.

In Youm's research (2013), South Korean parents commented that parents' education in teaching music to children is necessary to convey knowledge for parents to better guide their children and they were taking serious actions to making an effort in the parent's education; In contrary, local parents showed a relatively poorer attitudes on parent's education, local parents are also showing a lack of motivation to proceed with the related training.

The result from this study revealed some preliminary findings on parental attitudes as well as the awareness of the parental roles among the local parents whose children are learning music. Even though parental attitudes were mostly positive with clear goals and adequate knowledge in music, local parents generally did not find a necessity to expand their understanding on music education.

Children's success in musical instrument learning can rely on a more positive parental attitudes, moreover, a more efficient learning can come from better awareness of the parental roles among the parents. There should be a rising concern for music educators to find out a way to work more closely with the parents, including to help raise the awareness of parental roles for parents to maximize their potential roles into better guiding and supporting their children in music learning.

\section{References}

Bohner, G., \& Dickel, N. (2011). Attitudes and Attitude Change. Annual Review of Psychology, 62(1), 391-417. doi: 10.1146/annurev.psych.121208.131609

Chanda, M. L., \& Levitin, D. J. (2013). The neurochemistry of music. Trends in Cognitive Sciences, 17(4), 179-193. doi: 10.1016/j.tics.2013.02.007

Davidson, J. W., Sloboda, J. A., \& Howe, M. J. A. (1996). The role of parental influences in the development of musical performance. British Journal of Developmental Psychology, 14, 399-412. doi: 10.2307/40318764

Gersema, E. (2016). Children's brains develop faster with music training - USC News. Retrieved June 20, 2020, from https://news.usc.edu/102681/childrens-brains-develop-fasterwith-music-training/

Hallam, S. (1998). Instrumental teaching: A practical guide to better teaching and learnin. Oxford: Heinemann Educational Publishers.

Kilic, I. (2012). The problems of music teachers in primary education schools in turkey and solution offers. Procedia - Social and Behavioral Sciences, 51, 209-215. doi: 10.1016/j.sbspro.2012.08.147

$\mathrm{Ku}, \mathrm{M}$. (2006). Teacher's recognition and the status of the music education for early childhood in an educational institute. University of Suwon, Suwon, South Korea.

Margiotta, M. (2011). Parental support in the development of young musicians: a teacher's perspective from a small-scale study of piano students and their parents. Australian Journal of Music Education, 1(1), 16-30. 
http://search.proquest.com/docview/916423296?accountid=11440

McPherson, G. E. (2009). The role of parents in children's musical development. Psychology of Music, 37(1), 91-110. doi: 10.1177/0305735607086049

McPherson, G. E., \& Zimmerman, B. J. (2002). Self-regulation of musical learning: A social cognitive perspective. In R. Colwell \& C. Richardson (Eds.), The new handbook of research on music teaching and learning. New York: Oxford University Press.

Nam, S. H. (2006). In-service teacher's perception of the status of children's music education in early childhood teacher nurture curriculum and its improvement measures. Ewha Womans University, Seoul, South Korea.

Ogbeiwi, O. (2018). General concepts of goals and goal-setting in healthcare: A narrative review. Journal of Management and Organization, 1-18. doi: 10.1017/jmo.2018.11

Patton, M., \& Welch, J. K. (1992). Qualitative evaluation and research methods. The Modern Language Journal, 76, 543. doi: 10.2307/330063

Pomerantz, E. M., Grolnick, W. S., \& Price, C. E. (2005). The role of parents in how children approach achievement: A dynamic process perspective. In A.J. Elliot \& C.S. Dweek (Eds.), Handbook of competence and motivation (pp. 259-278). New York: Guilford.

Ritter, S. M., \& Ferguson, S. (2017). Happy creativity: Listening to happy music facilitates divergent thinking. PLOS ONE, 12(9). doi: 10.1371/journal.pone.0182210

Schwandt, T. (2011). The SAGE dictionary of qualitative inquiry. The SAGE Dictionary of Qualitative Inquiry. doi: 10.4135/9781412986281

Skoe, E., \& Kraus, N. (2012). A little goes a long way: How the adult brain is shaped by musical training in childhood. Journal of Neuroscience, 32(34), 11507-11510. doi: 10.1523/JNEUROSCI.1949-12.2012

Trappe, H. J., \& Voit, G. (2016). The Cardiovascular Effect of Musical Genres. Deutsches Arzteblatt international, 113(20), 347-352. doi: 10.3238/arztebl.2016.

Youm, H. K. (2013). Parents' goals, knowledge, practices, and needs regarding music education for their young children in South Korea. Journal of Research in Music Education, 61(3), 280-302. doi: 10.1177/0022429413497233

Zimmermann, B. J., \& Cleary, T. J. (2006). Adolescents' development of personal agency: The role of self-efficacy beliefs and self-regulatory skill. In F. Pajares \& T. Urdan (Eds.), SelfEfficacy Beliefs of Adolescents (pp.45-70). Greenwich, CT: Information Age Publishing. 